\title{
The Role of Badan National Narcotics (BNN) in Conducting Law Enforcement and Drug Users
}

\author{
Yudin Yunus $^{1 *}$, Siti Alfisyahrin Lasori ${ }^{1}$ \\ 1 Law Department, Universitas Ichsan Gorontalo, Indonesia \\ *Correspondence: yudinhamzahyunus@gmail.com
}

\section{ARTICLE HISTORY}

Received: 14.09 .2021

Accepted: 25.12.2021

Published: 31.12.2021

\section{ARTICLE LICENCE}

Copyright (C) 2021 The

Author(s): This is an

open-access article

distributed under the

terms of the Creative

Commons Attribution

ShareAlike 4.0

International (CC BY-SA

4.0)

\begin{abstract}
Law No. 35 of 2009 on Narcotics in which it is regulated as well as legal sanctions, as well as things that are allowed. The purpose of this study is to understand and understand the implementation of the Role of the National Narcotics Agency (BNN) towards the Implementation of Drug Abuse Rehabilitation in The City of Gorontalo and to find out the Factors That Hinder the Implementation of Rehabilitation of Victims of Narcotics Abuse by the National Narcotics Agency (BNN). This research uses this type of empirical legal research. The results of this study show that the Role of the National Narcotics Agency (BNN) against victims of narcotics abuse by the National Narcotics Agency (BNN) is the first is to prevent, cure, socialize socialization carried out by the city of gorontalo to the community is still very less this is influenced by the budget of the state budget that does not accumulate and factors that hinder the implementation of rehabilitation of victims of narcotics abuse by the National Narcotics Agency (BNN) is harmonization of agencies must be achieved Budget constraints, low role and lack of facilities and infrastructure and lack of socialization. there are things that can hinder others but do not have significant impact as in the factors found if not met will slow the performance of law enforcement. The advice in this study is that the BNN Party maximizes socialization to the community because of the three roles of BNN socialization that has not run optimally and advice for the community and local governments and students can participate in drug eradication to achieve superior human resources.

Keywords: BNN;Narcotics;Users
\end{abstract}

\section{Introduction}

Law No. 35 of 2009 on narcotics, providing solutions and categories of sanctions in criminal law is also followed up by the regulation of the Republic of Indonesia No 23 Tahun 2010on national narcotics agencies (BNN) which in article 1 describes the National Narootics Agency which is further in the Presidential Regulation of the Republic of Indonesia is called BNN is a non-ministerial government agency domiciled under and responsible to the President through coordination of the Head of state police of the Republic of Indonesia and has a function in article 3 paragraph 1 prevention and eradication of the abuse and illicitcirculation of narcotics, psychotropics, and precursors and materials. Other addictive substances except addictive ingredients for tobacco and alcohol. (Presidential Regulation No. 23 of 2010 concerning the National Narcotics Agency, n.d.) The scope and substance stipulated in this Act is broader with more severe criminal threats. (Kolopita, 2013)

Narcotics and drug crimes in the present have been transnational in nature carried out with a high modus operandi and advanced technology, law enforcement officials are expected to be able to prevent and overcome these crimes to improve morality and quality of human resources in Indonesia, especially for the next generation of the nation. Among the law enforcement officials who also have an important role in the existence of narcotics cases is the National Narcotics Agency (BNN), which is expected to be able to help the law enforcement process against narcotics crimes.

In Law No. 35 of 2009 on Narcotics in which legal sanctions are regulated, as well as things that are allowed, the National Narcotics Agency is expected to be able to help the process of resolving cases against someone or more who have committed narcotics crimes today. In Law No. 35 of 2009 on Narcotics, the National Narcotics Agency is given the authority to conductinvestigations and investigations, which has not been regulated 
in the old law. Two authorities are deemed necessary to anticipate narcotics crimes with an increasingly complex modus operandi and supported by a network of organizations. Not only the addition of authority, the institutional status of the National Narkotika Agency was also improved. Regarding the Rehabilitation program of BNN, Gorontalo city has revealed that from 2017 to 2020 the number of people recommended for rehabilitation as drug pecandu is as many as 57 people who have an age considered still productive from the age of 13 to 30 years above shows that drug users in Gorontalo Province, especiallyGorontalo City It ranks first followed by Pohuwato Regency. (BNN Gorontalo Rehabilitation of 500 Drug Addicts, 2929)

Thatalmost 217 people in Rehabilitation, especially the city of Goronratalo over the last three (3) years, are all drug users who experience severe addiction, moreover, there are some addicts who undergo rehabilitation more than once due to severe addiction, but if the reality with rehabilitation does nothave a significant impact in solving the problem. The author expects a solution to be found in the proposal of this study to find the best solution, that the role of BNN in reducing narcotics users does not work well than expected but in fact almost every year drug users are getting higher.

\section{Methodology}

The author's research uses this type of empirical normative research. The location of this study was conducted at the office of the National Narcotics Agency of Gorontalo City because the BNN of gorontalo city was recorded as the best offender in the field of narcotics compared to other haze. The population of this study is (1) Narcotics Users, (2) Parents (3), BNNEmployees, (4) Communities. The sample is a. BNN employees as manyas 2 people. b. Narcotics users as many as 2 people. C. Parents as many as 2 people. d. People as many as 4 people. The data sources used in this study are primary data and secondary data. Data analysis techniques revealed by Soerjono Soekanto that the procedure for deciphering data in the form of sentences, arranged and interpreted systematically, in order to reach conclusions. The data analysis used in this research proposal is qualitative analysis and qualitative methods use how to decipher data and information obtained from the research location from those with general properties to special properties in accordance with the research problems carried out. (Soekanto, 2008)

\section{Result}

\subsection{The Role of the National Narcotics Agency (BNN) Terhadap Implementation of Drug Abuse Rehabilitation in Gorontalo City}

Rehabilitation if we see clearly that rehabilitation is a process to recover a person from the effects of drug addiction. (Roni Gunawan Raja Gukguk, 2019) Pthere is a fact that Rehabilitation is a comprehensive way in its approach, because the purpose of Rehabilitation is none other than to reshape the ability in terms of physical aspects, behavior, mental and social behavior in everyday life (Kartika et al., 2015), in the fulfillment of the rehabilitation process is actually a process carried out by a person. To treat itself in a pre-established procedure for a rehabilitationexpert, rehabilitation experts provide an overview and direction on the healing and recovery process so that rehabilitation patients can follow and do all directions for the healing process due to the use of illegaldrugs. (Jonah, 2020)

If we look at the legal basis of the standard rehabilitation process applied in the form of laws and regulations as stipulated in:

a) Law No. 22 of 1997 on Narcotics

In this law he explained about the clastication of narcotics between stated in article 1, namely what is meant by narcotics is substances or substances derived from plants or not plants either synthesis or semi-synthesis that can cause decreased orchange of consciousness, loss of taste, reduce to relieve pain.

b) Presidential Regulation No. 17 of 2002 concerning the National Narcotics Agency in the law explaining the duties of BNN clarified in article 2, namely BNN has the task of assisting the president in coordinating the relevant government agencies in the preparation of policies in the field ofavailability, prevention and eradication of abuse and illicitcirculation of prequerary psychotopic narcotics and other adjukti substances. 
c) Law No. 35 of 2009 on Narcotics Some of the above laws and regulations have regulated the implementation of rehabilitation in the second place, but the implementation of rehabilitation of drug users is regulated in Law No. 35 of 2009 on narcotics,

Berdasarkan buyi article 54 "Drug addicts and victims of narcotics abuse must undergo medical and social rehabilitation"

Porigin 1 number $23 \mathrm{KUHAP}$ which confirms that a person's right to obtain the restoration of his or her right to the ability, position,and dignity granted at the level of investigation, prosecution, or trial for being arrested, detained, prosecuted or tried without reason under the Act or by mistake regarding his war or the law applied in the manner stipulated in the Act.

Based on the results of the tian researchthatwas obtainedbythe fact that the number of participants over the last four years that

Table 1. Gorontalo City BNN Rehabilitation Data

\begin{tabular}{cccccc}
\hline \multirow{2}{*}{ No. } & \multirow{2}{*}{ Year } & \multirow{2}{*}{ Data } & \multicolumn{2}{c}{ Rehabilitation } & \multirow{2}{*}{ Total } \\
\cline { 4 - 5 } & & & Stay & Road & \\
\hline 1 & 2018 & 28 & 1 & 27 & 28 \\
\hline 2 & 2019 & 58 & 4 & 54 & 58 \\
\hline 3 & 2020 & 15 & & 10 & 15 \\
\hline 4 & $\begin{array}{c}\text { January to } \\
\text { March 2021 }\end{array}$ & 16 & - & 16 & 16 \\
\hline
\end{tabular}

\section{Source: BNN Kota Gorontalo}

From the data compiled in several years of Drug Case Data in 20188-20 20 BNN Gorontalo City that there are 117 cases of drug rehabilitation where every know starts from 2018 there are fifteen(28)drug cases in Itasi, in2019 there are sixteen (58)drug cases thatareidentified, and in 2020 ada thirty(15)drug cases are Rehabilitated.

Rehabilitation in BNN Gorontalo City is the stage of medical rehabilitation to return drug addicts to be healthier and recover from addiction, This rehabilitation focuses more on medical ways or involves experts in the world of health such as doctors, rehabilitation nurses and medical rehabilitation instructors, to perform treatment and assistance to patients Rehabilitation, Rehabilitation medically usually if the patient has organ damage due to dependence on illegal drugs such as nerve damage, and the nervous system so that medical and extra treatment is needed.

The findings of the study are that narcotics cases in the city of gorontalo are increasing day by day of course the awareness of the people of gorontalo city related to narcotics is still very lacking so that although the BNN of gorontalo city has worked with maximum prevention it is difficult to achieve this is evidenced by the number of rehabilitation patients every year increases, while in 2020 with budget constraints due to Indonesia due to the disaster of pandemic covid 19 as a work program from BNN city is not fully implemented.

Based on the results of an interview with one of the Chairpersons of BNN of Gorontalo City, Mr. Audi Rudolf Jantu,gave an overview of rehabilitation that (Resultsof Interview in Bnn Office of Gorontalo City with Mr. Audi Rudolf Jantu on February 19, 2021): All of our heavy narcotic addicts strive to recover both physically and spiritually, many addicts are on average in rehabilitation at the request of heaven or on the basis of a court order."

As stated by Dr. Kevin Adrian that:

1) Pre-Rehabilitation (Stage of Medical Rehabilitation)

At this stage of Pre Rehabilitation drug users are required to check medically how high the level of drug addiction is experienced by the addict so that the medical officer or rehabilitation officer can determine the level and pattern of rehabilitation needed.

2) Rehabilitation Stage (Rehabilitation Stage)

Thisstage is the stage where drug users perform Rehabilitation both medically and nonmedically through training and rehabilitation nurses,

3) Healing (Advanced Level) 
This stage is the stage where drug addicts who have been considered recovered but still have to do further coaching so as not to fall back into the world of narcotics. (Kevin, 2021)s

It is in line with what is obtained on the ground that the rehabilitation stage is carried out based on legal orders but even though the implementation of rehabilitation has not been maximal due to several factors as the results of interviews with BNN employees of Gorontao Province mentioned that harmonization of agencies, budgetconstraints and facilities and infrastructure. Of course this becomes a homework for BNN Gorontalo Province, to spur fresh air in the form of Prima servants to the community providing advice and education, besides that all that is needed in the form of budget is very urgent to be held even though in its use it is still considered unimportant. (Mursanto, 2018)

\subsection{Prevention}

Based on the results of an interview with Audi Rudolf jantu Kasubag BNN Kota gorontalo. According to rudolf, Factors cause the risk of using drugs among teenagers and school children and youth, especially in the city of Gorontalo after our interview was the first time just want to try because of the poor environmental association and examples of his friends. The feeling of wanting to try these narcotics is the first entrance and the cause of young people are plunged into the negative impact of drug abuse and illegal drugs that endanger health in the future.

We from the BNN of Gorontalo City havea role in prevention has done so by making and providing tips on avoiding drugs Here are some tips on avoiding drugs that we have investigated and we must socialize in the community to do prevention, namely:

1. Never try to use narcotics, except on the basis of medical or medical considerations.

2. Know about the various bad effects of drugs.

3. Choose a good association and stay away from relationships that can lead us to drug abuse.

4. Have positive activities, exercise or even follow organizational activities that have a positive influence on us.

5. Always remind the threat of punishmentfor drug abusers, especially for drug dealers is a penitentiary.

6. Use a safe time and place, do not go out at night. Relax with family, beraraoke, picnic, eat together, cook together, get clean with watching with family.

7. If you have a problem then find a good way out and do not make drugsasa way of escape. (Resultsof Interview In Bnn Office of Gorontalo City With Mr. Audi RudolfJantu on February 19, 2021)

\subsection{Doing Healing}

This stage is the stage where drug addicts who have been considered recovered but still have to do further developmentso as not to fall back into the world of healing narcotics Rehabilitation if we see clearly that rehabilitation is a process to recover someone from the consequences of drug addiction, in essence Rehabilitation is a way that is considered comprehensive in the world of drug rehabilitation. The approach, because the purpose of rehabilitation is none other than to reshape the ability in terms of physical aspects, behavior,mental and social behavior in his dailylife, in fulfilling the rehabilitation process is actually a process carried out by a person to treat himself in a predetermined manner for a rehabilitation expert, rehabilitation experts provide an overview and direction on the healing and recovery process so that for rehabilitation patients can follow and perform all instructions for the healing process due to the use of illegal drugs. This rehabilitation function is the same as the legal function to treat humans from all problems. (Greetings, 2020)

Based on the results of Murianto Ibrahim's interview as a counselor at BNN Kota Gorontalo From the interview with Murianto lbrahim That the healing process consists of 3 stages, namely the first stage is Ovverview which is to stop from a use slowly slowly, Reccovery Ditahap is a patient in trying to stop Total, set it early recorvery at this stage the patientbegins to be trained to adaptlightly to life without using narcotics, Middle Recorvery at this stage the patient begins to belate by improving other factors by improving his Late Recovery. (The results of Murianto Ibrahim's interview as a counselor at BNN Kota Gorontalo on February 2, 2021) 
The result of the interview conducted at the time of research with one of the rehabicitating patients, revealed that the first time aboutdrugs is the result of daily association inman he hangs out, after then drug use increasingly climbing and actively consuming drugs, even has twice entered BUI because of using drugs then finally the last one was determined to InRehabilitation, because it has been very long using narkoba finally dependency As for rehabilitation patients who are pegged revealed that the sex: women age: 32 years initials GLInterviewresults: first known since junior high school tried addictive substances \& increased to marijuana \& meth in high school. Patients have been arrested several times in rehabilitation,patients are difficult to stop because they have long been a user.

It is also revealed by lidya that narcotics are types of drugs that contain the effects of this type of dependence mentioned that the type used through inhalation, eaten and smoked swallowed or injected that will attack the nervous system causing a decrease in brain performance due to a sense of dependence. (Joewana, 2006)

Therefore, at this stage of healing must be more total both in terms of control and in terms of social assistance so that the victim does not return to the environment that makes him fall is usually known as social rehabilitation Rehabilitation rehabilitation is known for its approach to the environmental approach where rehabilitation patients live (Salam, 2017), this rehabilitation aims to restore social behavior and prioritize behavior in the environment, especially if the occurrence of mental disabilities. Rehabilitation patients are considered important in recovery so that patients are stronger and more confident to return to society. Of course, if the rehabilitationand healing process of drug addict patients has been successfully part of the enforcement of usefullaw.

\subsection{Doing Socialization}

Theyare particularly vulnerable to drug abuse, as they are still in the transition from childhood to adulthood, so there are many new things they want to know and sometimes try. From there, it needs knowledge for them, one of which is about the threats and dangers of drug abuse that begin to lurk in their surroundings. If there is one of their friends who becomes a abuser, then most likely they will be curious and want to feel it.

For this reason, the importance of socialization to the community, especially for ad olescents in order to provide knowledge to the community but we realize that the socialization carried out by the city of gorontalo bnn to the community is still very less this is influenced by the budget of the state budget that does notaccumulate even though the work program has been well organized about the stages of socialistization because we realize that socialization is the most important thing in the process of narcotics prevention for the people of Gorontalocity. (The results of an interview with Mr. Audi Rudolfat the BNN Office of Gorontalo City.

\section{Result}

\subsection{Harmonization Instansi}

The ability between investigators in the investigation process is the most important obstacle especially in this case the BNN and the police have different locations and institutions although the same in the enforcement of narcotics law, especially the BNN and the police should have synergy in eradicating drugs as the Gorontalo Police Drug Directorate and the Gorontalo Police Drug Unit are equally in combating narcotics.

Apabila we claima jinoramatively regarding the tupoksi of each performance of the BNN and Piha police in terms of regulations has been found that there is an inequality of authority as stated in Article 21 of Presidential Regulation No. 23 of 2010 concerning the National Narcotics Agency on Deputy for Rehabilitation has the task of carrying out the task of carrying out prevention and eradication of drug abuse and illicit circulation (P4GN) specifically in the field of Rehabilitation, which means having a duty to eradicate drug trafficking while the police also have a duty to be regulated based on the KUHAP which mandates strictly

Article 37 states that:

a) At the time of arresting the suspect, investigators are only authorized to search clothes including objects he carries and, if there is a strong suspicion with sufficient reason that the suspectcan be confiscated.

b) At the time of arresting the suspect or in the case of the suspect referred to in paragraph (1) is brought to the investigator, the investigator is authorized to search the clothes and or search the body of the suspect. 
Therefore, based on kuhap the police also have authority in combating drug crimes, of course this becomes a stumbling block for both diamonds if there is no synergy between the two sides of the problem of authority in eradicating drugs. Simply put, it can be described that if in conducting an investigation then in the process of assement the police will conduct an investigation into the criminal offense of the drug based on the order of the Kuhap.

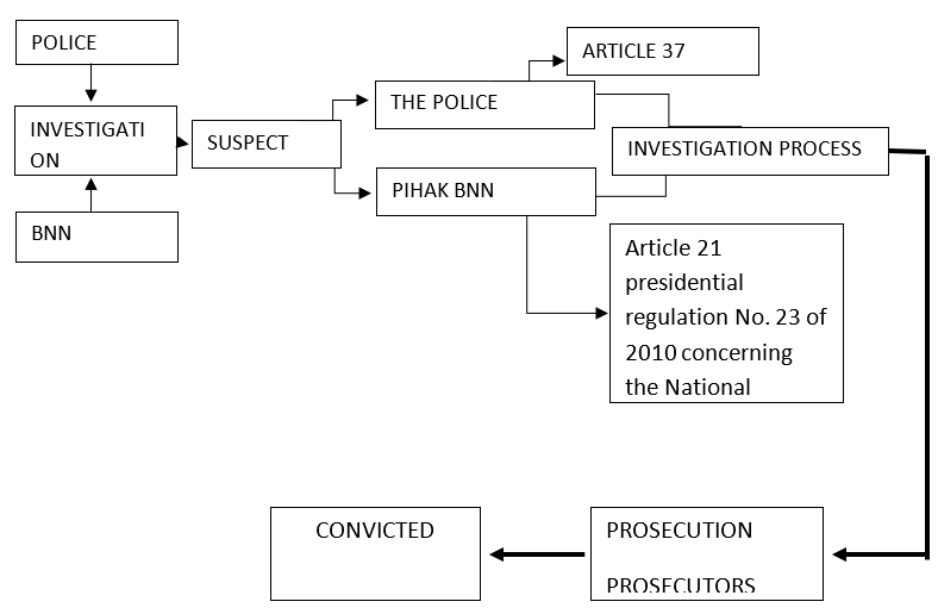

Picture 1. A Chart Of Proses Investigation Antara Policeand BNN

Based on the flow chart above it is explained that a suspect can be investigated by the Police and BNN parties because of the basic rules that give both of the authorities authority to conduct investigations based on article 37 of the Kuhap while the BNN Party conducts investigations based on article 21 perpres number 23 of 2010 concerningBNN. Based on the results of an interview with one of the BNN investigators revealed that (BNN Interview Results on Thursday, February 20, 2020):

"Basicallywhen in law enforcement regarding narcotics but sometimes there is a slight delay in taking policy between BNN and the police in order to ensure suspects and victims can be handled in an appropriate manner".

Of course, there are certain limits that must be addressed by both parties of the institution so that synergy in drugeradication. Based on the overlap in the use of drugs above, according to the author who is a result in the inhibition of the rehabilitation process of drug users is the difference in data between police investigators and the BNN of Gorontalo Province with data owned by the Gorontalo Police Department (Directorate of Drug Reserse (Ditresnarkoba) Gorontalo Police) in the prosecution of some drug users does nothave the same data between the police institution and the BNN so that the Rehabilitation process is considered slow, This is of course if we see simply that in determining whether a suspect is worthy of rehabilitation or notis during the process of investigation and investigation, in the process of investigation and investigation of course the police and BNN are different but the object to be addressed is the same, namely drugs.

\subsection{Budget Constraints}

Budget is one of the decisive intrusions in moving the wheels of performance in a governmentsystem or in an institution, the budget in the form of funds disbursed every year for large diamonds such as BNNP Gorontalo Province for the benefit of law enforcementand rehabilitation process for drug users andaddicts. In the results of the interview in general the budget is not adequate, in determining the procurementand expenditure of each item of interest both law enforcement and control interests are still somewhatminimal such as
a) Extension budget
b) Socialization budget
c) Budgetin the framework of operatinal work programs
d) Rehabilitation treatment budget 
But the procurement budget in the form of facilities and infrastructure is also based on its own rules and policies from the center as to what the needs of each BNN in the province or the area of each jurisdiction but the results of the interview are not mentioned in detail about the budget used in the rehabilitation process. According to the source of rehabilitation officers from BNN, applying for certain patients (suchas patients who have a very high level of dependence and mustbe hospitalized) in order to be referred/transferred to a state owned rehabilitation place that is better facilities/ facilities and infrastructure but often not maximal bias because of limited so that patients are in the hospital. Rehabilitation in a place that is in accordance with the existing budget, which according to the source of facilities and infrastructure/ facilities in the place is still less mmadai, so that due to the limited budget of rehabilitation implementation becomes not maximal.

\subsection{Low Participation of Society}

The role of society here is one of the inhibiting factors due to some factors that involving themselves with the law is one of the complicatedbehaviors, so that it gives rise to nonchalant behavior in the eradication of narcotics users, the role and the future are needed by law enforcement especially the BNN to know clearly and precisely about the problem. drug trafficking. The participation of the community here as expressed by BNNP Gorontalo employee Budi Kurniawan Kiyai, SH that

Thecommunity is actually not indifferent however, the community tends to be afraid to involve themselves with Law Enforcement when talking about drugs is very rare for people who want to report even ordinary events of the community knowing but reluctant to report for fear of indtimidation or involving themselves from lawenforcement.

In addition to that actually if we examine the role of the community in the eradication of drug use can be seen in regulations that provide protection as in "article106 of the Narcotics Law regulating the form of community role in tackling drug abusers realized by;

a. Seeking, obtaining and providing information on allegations of criminal acts narkotika and narcotics prkursor

b. Obtaining services in finding, obtaining and providing information about the existence of suspected narcotics crimes and narcotic precursors to law enforcement or BNN who handle criminal cases narkotika and narcotic precursors

c. Get answers to questions about his report that were givento law enforcement or BNN

d. Obtain legal protection when the person concerned exercises his or her right to be required to appear in the judicial process

e. Report to the competent authorities or BNN if they are aware of abuse or illicitcirculation ofnarcotics and precursors"

Based on the results of interviews and discussions with BNNP gorontalo Employees, Mr. Budi Kurniawan Kian SH gave anidea that people are afraid to report because

1. I don't want to get involved in legal issues.

2. I don't want life to be disrupted.

3. The pattern of bullying thinking always looms for the complainant.

4. There is a sense of ignorance aboutdrugs (indifferent)

5. And even today it is very rare and very closed to the public regarding the information of existing drug users.

So according to the author, it is still needed in the form of attitudes and behaviors between law enforcement and the community in combating drugs where law enforcement is still required to increase public confidence and public knowledge through counseling and training programs that are educational for the community to stay away from and report every incident that exists about drugs, because several factors are found about the low participation of the community according to the results of the interview, namely the community does not want to involve Self in legal matters, Do not wantlife disturbed, The pattern of thinking intimidation always looms for the complainant, There is a sense of ignorance about drugs (indifferent) this occurs due to threats from others that involving themselves with drug dealers (Reporting) is a complicated and not easy matter 


\subsection{Lack of Facilities and Infrastructure}

Infrastructure facilities are tools or places that can support all forms of activity carried out by each agency in order to carry out good and appropriate service in the implementation of drug use in grorontalo diprovinsi regarding supporting facilities actually ingeneral have good facilities this is based on the results of observation and direct review of good spaciousness in terms of

When we look at the understanding offacilities and infrastructure in the KBBI dictionary states that means are everything that can be used as a tool in achieving a purpose or purpose. And infrastructure is everything that is the main supportfor the implementation of a process (business, development, project).

Table 2. the understanding offacilities and infrastructure in the KBBI dictionary

\begin{tabular}{|c|c|c|c|c|}
\hline No. & Means & Information & Infrastructure & Information \\
\hline 1 & $\begin{array}{l}\text { Operational } \\
\text { Vehicles }\end{array}$ & Exist & Building BNN & There'senough \\
\hline 2 & $\begin{array}{lr}\text { Means } & \text { of } \\
\text { Counseling and } \\
\text { Construction }\end{array}$ & Still Lacking & $\begin{array}{l}\text { Local Government } \\
\text { Hospital(Cooperation) } \\
\text { BNN Clinic }\end{array}$ & $\begin{array}{l}\text { Enough, but still } \\
\text { need to add }\end{array}$ \\
\hline 3 & Drugs & Still Lacking & $\begin{array}{l}\text { Human Resources } \\
\text { (Doctor of Therapy) }\end{array}$ & Very lacking \\
\hline 4 & $\begin{array}{l}\text { Rehabilation } \\
\text { Room }\end{array}$ & Still Lacking & & \\
\hline
\end{tabular}

a) Operational Vehicle Facilities used to pick up and deliver rehabilitation patients

b) The means of extension and construction mean that props in counseling and training rehabilitation patients are still minimal it is also limited in terms of budgetfor implementation achieved every know

c) Suggestions of medicines and medical equipment that are considered still there are lacking in the recovery of rhhabilitated fascia

d) Rehabilitation Room is a khusus room for rehabilitation patients where the room must meet the standards as it should be habitable patients, based on the results of research that in the rehabilitation process only uses one building and several people are still in one room.

Infrastructure

1. BNNP building is a building that will support the administrative process of rehabilitation patients so that it is considered quite gedunag owned by BNNP gorontalo city.

2. BNN clinic isa clinic owned by BNN which is in the BNN building but this clinic has limited medical equipment

3. Human resources are human resources that are considered minimal because of the limited doctors physiotrapi where the average doctor of physiotherapy almostall broughtfrom north sulawesi or south sulawesi.

Facilities and infrastructure are the most decisive things other than the budget because inadequate facilities and infrastructure can be ascertained the rehabilitation process can not be carried out properly. (Rizki, 2017) Based on the results of interviews with BNN officers of Gorontalo City provides an overview that

Actuallythe facilities and infrastructure are very adequate but some still need to be improved such as Urine Test equipment and other equipment to support prevention on the one hand is also the most important in the facilities of maintenance, namely maintenance funds even if infrastructure facilities are as good as anything if no periodic maintenance is done, it will certainly be quickly damaged and cannot be used properly.

If we look at the theory of Soerjono Soekanto said that the availability of facilities in the form of facilities and infrastructure for the implementing apparatus in doing its job. The facilities and infrastructure in question are infrastructure or facilities that are used as tools to achieve legal effectiveness. In connection with the facilities and infrastructure that are notedwith the term of this facility, especially for these facilities or facilities, it should be embraced jalan mind, as follows (Soekanto, 2008); 
a. The nothingthathas just been corrected;

b. Damaged or wrong- repaired or corrected;

c. Less-added;

d. The jam-dslanwn;

e. The retreat or degenerate-advanced or improved

Soerjono Soekanto predicts the benchmark effectiveness of certain elements of infrastructure, where the infrastructure must clearly be a part that contributes to the smooth running of the tasks of the apparatus in the place or location of work.

So according to the author about the facilities and infrastructure that become obstacles is very limited, but in addition to BNN infrastructure is also supported by human resources that complement each other in the rehabilitation process, but the facilities and infrastructure are also not so great an influence, as a inhibition because the use of facilities in general based on the data presented above is still considered sufficient but must also be maximized in the procurement of infrastructure so that it will be more achieved perlindugan and law enforcement that aspires to the high number of rehabilitation patients and drug users handled while the Rehabilitation Room is a special room for rehabilitation patients where the space mustmeet the standards as should be habitable patients, based on the results of research that in the rehabilitation process only uses one building and several people are still in one area can be completed properly by the provincial BNNP, One of them is but in the theory expressed by soerjono soekanto, it is also very useful to improve the quality and capacity in public services so that there are no deficiencies experienced by both law enforcement, rehabilitation patients and all elements involved in the implementation of good and appropriate services in the implementation of public services. Drug use in grorontalo diprovinsi regarding supporting facilities actually in general has good means this is based on the results of observation and direct review of spaciousness

\section{Conclusion}

The role of the National Narcotics Agency (BNN) against victims of narcotics abuse by the National Narcotics Agency (BNN) is the first is toprevent, cure, socialize socialization carried out by the city of gorontalo to the community is still very less this is influenced by the budget of the state budget that does not collectand factors that hinder the implementation of rehabilitation of victims of narcotics abuse by the National Narcotics Agency (BNN) is harmonization of agencies must be achieved Budget limitations, low role and community and lack of facilities and lack of socialization. there are things that can hinder others but do not have significant impact as in the factors found if not met will slow the performance of law enforcement. The advice in this study is that the BNN Party maximizes socialization to the community because of the three roles of BNN socialization thathas not run optimally and sranfor the community and local governments and students can participate in drug eradication to achieve superior human resources.

\section{References}

BNN Gorontalo Rehabilitasi 500 Pecandu Narkoba. (2929). Kronologi.Id.

Joewana, L. H. dan S. (2006). Pencegahan dan Penanggulangan Penyalahgunaan Narkoba Berbasis Sekolah. Balai Pustaka.

Kartika, A., Ablisar, M., \& Ikhsan, E. (2015). Aplikasi Kebijakan Hukum Pidana Terhadap Pelaksanaan Rehabilitasi Pecandu Dalam Tindak Pidana Narkotika (Studi Di Rehabilitasi Kementerian Sosial Pamardi Putra "Insyaf' Sumatera Utara). USULaw Journal, 3(1), 44-55.

Kevin, D. (2021). Tahapan Rehabilitasi Narkoba. Alodokter.

Kolopita, S. P. (2013). Penegakan Hukum Atas Pidana Mati Terhadap Pelaku Tindak Pidana Narkotika. Lex Crimen, II(4), 63-71.

Mursanto, D. (2018). Pelaksanaan Keadilan Restoratif Terhadap Anak Sebagai Kurir Narkotika. Jurnal Hukum Volkgeist, 3(2015), HIm. 38-47.

Peraturan Presiden RI Nomor 23 tahun 2010 Tentang Badan Narkotika nasional. 
Rizki, K. (2017). Proses Penyidikan dan Faktor Penghambat Pemberian Rehabilitasi Terhadap Korban Penyalahgunaan Narkotika. BNN Sumatera Selatan.

Roni Gunawan Raja Gukguk, N. S. P. jaya. (2019). Tindak Pidana Narkotika Sebagai Transnasional Organized Crime. Jurnal Pembangunan Hukum Indonesia, 1(3).

Salam, S. (2017). Analysis of Cooperation Agreements and Comparison Patterns of Out-of-Court Dispute Resolution. Jurnal Hukum Volkgeist, 2(1), 71-81.

Salam, S. (2020). Rekonstruksi Paradigma Filsafat IImu : Studi Kritis Terhadap IImu Hukum Sebagaillmu. Ekspose: Jurnal Penelitian Hukum Dan Pendidikan, 18(2), 885-896. https://doi.org/10.30863/ekspose.v18i2.511

Soekanto, S. (2008). Faktor-Faktoryang Mempengaruhi Penegakan Hukum. PT Raja Grafindo persada.

Yunus, Y. (2020). Juridical Review Of The Authority Of The Indonesian Consultative Assembly After The Amendments To The 1945 Constitution. Jurnal Hukum Volkgeist, 5(1), 34-44. 